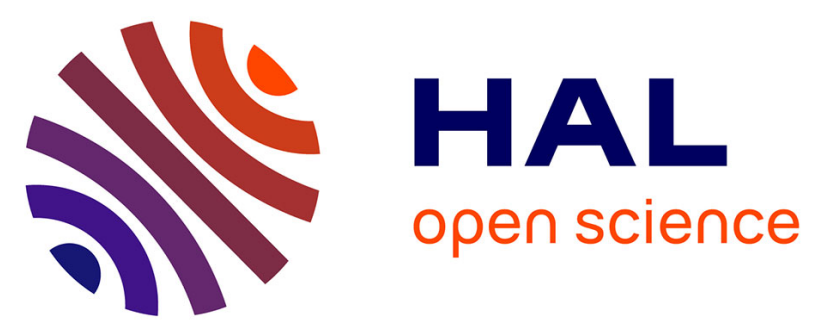

\title{
Sub-Ocean: Subsea Dissolved Methane Measurements Using an Embedded Laser Spectrometer Technology
} Roberto Grilli, Jack Triest, Jérôme Chappellaz, Michel Calzas, Thibault Desbois, Pär Jansson, Christophe Guillerm, Benedicte Ferré, Loic Lechevallier, Victor Ledoux, et al.

\section{To cite this version:}

Roberto Grilli, Jack Triest, Jérôme Chappellaz, Michel Calzas, Thibault Desbois, et al.. Sub-Ocean: Subsea Dissolved Methane Measurements Using an Embedded Laser Spectrometer Technology. Environmental Science and Technology, 2018, 52 (18), pp.10543 - 10551. 10.1021/acs.est.7b06171. hal-01913459

\section{HAL Id: hal-01913459 \\ https://hal.science/hal-01913459}

Submitted on 6 Nov 2018

HAL is a multi-disciplinary open access archive for the deposit and dissemination of scientific research documents, whether they are published or not. The documents may come from teaching and research institutions in France or abroad, or from public or private research centers.
L'archive ouverte pluridisciplinaire $\mathbf{H A L}$, est destinée au dépôt et à la diffusion de documents scientifiques de niveau recherche, publiés ou non, émanant des établissements d'enseignement et de recherche français ou étrangers, des laboratoires publics ou privés. 


\section{Sub-Ocean: Subsea Dissolved Methane Measurements Using an Embedded Laser Spectrometer Technology}

Roberto Grilli, ${ }^{*}{ }^{\dagger}$ Jack Triest, ${ }^{\dagger}$ Jérôme Chappellaz, ${ }^{\dagger}$ Michel Calzas, ${ }^{\ddagger}$ Thibault Desbois, ${ }^{\S}$ Pär

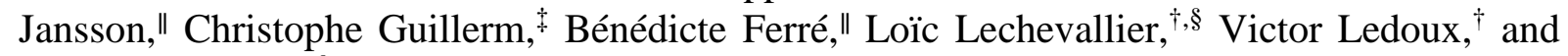
Daniele Romanini ${ }^{\S}$

${ }^{\dagger}$ Université Grenoble Alpes, CNRS, IRD, Grenoble INP, Université Grenoble Alpes, IGE, F-38000 Grenoble, France

CNRS DT INSU, 29280 Plouzané, France

$\S$ Université Grenoble Alpes, CNRS, LIPhy, F-38000 Grenoble, France

" CAGE - Center of Arctic Gas Hydrate, Environment and Climate, Department of Geology, UiT University of Norway, N-9019 Tromsø, Norway

* Corresponding Author: Roberto Grilli. Phone: +33 (0) 4768242 66. E-mail: roberto.grilli@cnrs.fr. Corresponding author address: Institut des Géosciences de l'Environnement (IGE), Université Grenoble Alpes, 54 rue Moliére - BP 96, 38400 St. Martin d'Hères, France. 
Abstract. We present a novel instrument, the Sub-Ocean probe, allowing in situ and continuous measurements of dissolved methane in seawater. It relies on an optical feedback cavity enhanced absorption technique designed for trace gas measurements and coupled to a patent-pending sample extraction method. The considerable advantage of the instrument compared with existing ones lies in its fast response time of the order of $30 \mathrm{~s}$, that makes this probe ideal for fast and continuous 3D-mapping of dissolved methane in water. It could work up to $40 \mathrm{MPa}$ of external pressure and it provides a large dynamic range, from subnmol of $\mathrm{CH}_{4}$ per liter of seawater to $\mathrm{mmol} \mathrm{L}^{-1}$. In this work, we present laboratory calibration of the instrument, intercomparison with standard method and field results on methane detection. The good agreement with the headspace equilibration technique followed by gas-chromatography analysis supports the utility and accuracy of the instrument. A continuous $620-\mathrm{m}$ depth vertical profile in the Mediterranean Sea was obtained within only 10 min and it indicates background dissolved $\mathrm{CH}_{4}$ values between 1 and $2 \mathrm{nmol} \mathrm{L}^{-1}$ below the pycnocline, similar to previous observations conducted in different ocean settings. It also reveals a methane maximum at around $6 \mathrm{~m}$ of depth that may reflect local production from bacterial transformation of dissolved organic matter.

\section{Introduction}

The measurement of dissolved gases in a liquid medium (notably in water) is essential for different applications, such as environmental monitoring, search for natural gas reservoirs in the seafloor, deep-sea oil and gas pipeline inspection, monitoring the activity of bioreactors, safety control of industrial facilities or monitoring water quality (notably shale gas fields). In the field of environmental monitoring, a topic of particular 
focus over the last two decades has been the investigation of the fate of methane hydrate degassing from the seafloor and its relationship with global warming. ${ }^{1}$ Although methane released from hydrate reservoirs in the sediments appears to be mostly oxidized in the water column (see Ruppel and Kessler 2017 for a recent review), its contribution to ocean acidification is still under debate. ${ }^{2,3}$ Therefore, a quantitative evaluation of methane fluxes from the seafloor in gas hydrate-bearing regions remains needed, as well as the spatial and temporal dissolved methane evolution along the water column due to aerobic oxidation, diffusion, and transport. Other important scientific issues also require in situ measurements of dissolved methane, like the interactions between seasonal thawing of permafrost and organic transfer through Arctic river systems or methane fluxes from deep ocean seeps. These devices are also important in the study of microbial methane production in the oxic waters of oceans and lakes, a source of methane that can be important for carbon cycling in the aquatic environments and water to air methane fluxes..$^{4-7}$

In the last years to decades, knowledge of physical properties of ocean surface water has been considerably improved thanks to remote (satellite) measurements ${ }^{8,9}$ and nearsurface water sampling and analysis. However, three-dimensional distributions of dissolved gases are far less constrained since marine subsurface environments are more difficult to access. Parameters such as temperature, salinity, and oxygen are acquired using instruments such as a CTD (conductivity, temperature, and depth devices) that can run autonomously and can be implemented in floats, moorings, and gliders. ${ }^{10}$ Information about dissolved trace gases is more commonly extracted using discrete sampling (employing Niskin bottles) followed by laboratory measurements. This process is time consuming and provides data with poor spatial and temporal resolution, not adapted for understanding environmental processes that are highly variable in space and/or time. In 
some situations, water samples degassing from the Niskin bottles have been observed during the ascent, causing a degradation of the samples. ${ }^{11}$ Furthermore, in the case of supersaturated samples, outgassing during water sampling is difficult to prevent or quantify, leading to a possible underestimation of the amount of dissolved gas in deep waters. For these reasons, in situ instrumentation has more recently been developed, with the aim to provide more reliable (less sample manipulation) and fast measurements of dissolved gases. Most of it relies on embedded optical devices or mass spectrometers (MS). A review on the available sensors has been presented by Boulart et al. ${ }^{12}$ discussing the performances of existing commercial devices and other systems based on membrane separation, equilibrators, and in situ MS. Apart from in situ MS, ${ }^{13}$ the other approaches have limited response time (on the order of tens of minutes and mainly limited by the extraction method), making these devices less suitable for fast 3D mapping applications. ${ }^{14}$ In situ MS provide acceptable sensitivity and response time, but are often not sensitive enough for background concentrations. Their deployments as a stand-alone instruments are limited by the payload, power consumption, and cost. Furthermore, application of MS can suffer from interferences due to the presence of water vapor in the analyzed gas mixture, while optical techniques can work in spectral regions where water absorption is weak. If isotopic ratio MS (IRMS) are currently not compact enough to be embedded in subsea probes, optical spectrometers have already been successfully embedded in subsea sensors for in situ isotopic analysis, with applications to deep-sea measurements. ${ }^{15,16}$ Today, optical techniques are largely employed for in situ high resolution measurements of gas mixtures either directly in the atmosphere (from ground measurements to airborne monitoring or stratospheric balloons measurements), in ice cores (in the laboratory ${ }^{17}$ but soon also in situ ${ }^{18}$ ) and finally for measuring dissolved gases in liquids. The use of optical resonators and multipass cells can considerably increase the sensitivity with respect to 
direct absorption techniques, leading to robust and compact devices with small sample volume, easy to implement into a specific probe for field applications that require small sample flow. In this work we used optical feedback cavity enhanced absorption spectroscopy (OFCEAS), ${ }^{19,20}$ and further information can be found in Morville et al. ${ }^{21}$ The employment of this technique for dissolved gas measurements leads to advantages such as multiple species detection and the possibility to avoid interferences such as the presence of water vapor and other species present in the gas mixture (e.g. other hydrocarbons).

In this work, we describe the first application of the OFCEAS technique - combined with a patent-pending gas extraction module ${ }^{22}$ - for in situ real-time measurements of dissolved methane in seawater. Measurements have been conducted as a proof-ofconcept in the Mediterranean Sea in July 2014.

\section{Materials and Methods}

\subsection{The in Situ Sensor}

The optical instrument used in this study is the SUBGLACIOR spectrometer, ${ }^{18}$ developed as a drilling probe embedded device for in situ real-time measurements of air bubbles trapped in Antarctic glaciers. ${ }^{23,24}$ As a new design, it required calibration and testing in real environments before deployment to Antarctica, and the Mediterranean Sea was for us a good compromise (because of temperature fluctuations and increase of pressure with depth) even though not as extreme as Polar Regions. The spectrometer was made of an optical part that fits in a tube of $6.3 \mathrm{~cm}$ external diameter and $1.3 \mathrm{~m}$ long and an electronic part ( $8 \mathrm{~cm}$ ext. diameter, $1.2 \mathrm{~m}$ long). The optical-spectrometer, based on the OFCEAS technique, has been fully described by Grilli et al. ${ }^{18}$ and was designed for 
measuring simultaneously $\mathrm{CH}_{4}$ and $\delta \mathrm{D}$ of $\mathrm{H}_{2} \mathrm{O}$. The dissolved air from the extraction unit (discussed below) was continuously pumped to the optical cavity of the spectrometer. The internal volume of the cell is less than $20 \mathrm{~cm}^{3}$ and provides sample residence times $<30 \mathrm{~s}$ for optimal running conditions (combination of pressure and total gas flow). The instrument was equipped with an embedded PC, for processing and storing the data. Two protocols were implemented in order to communicate with the instrument during the field campaign. The first one used a wireless connection (ad-hoc network configuration), providing easy access to the embedded instrument via a PC-PC communication. The second protocol employed cabled communication, allowing realtime transfer of data together with remote control of the spectrometer, if necessary.

Extraction of dissolved gases from seawater was performed using a silicon rubber membrane, for which the technology has previously been described in terms of physical properties such as adsorption, permeation, and desorption. ${ }^{25-30}$ Existing sensors, including commercial instruments from Contros (Kongsberg), Franatech, Los Gatos Research and Pro-Oceanus, employ membrane extraction for measuring dissolved gases. ${ }^{31,32}$ Membrane extraction techniques found in the literature rely on gas equilibration across the membrane that allows for precise measurements of dissolved gas concentration, at the cost of slow response time ( $>20 \mathrm{~min}) \cdot{ }^{14,33}$ Here, we propose a different approach consisting of maintaining the dry side of the membrane at low pressure, while continuously flushing it with dry "zero" gas. The pressure at the membrane dry side controls the total flow of dry and wet air through the membrane, and the system was designed to keep this pressure constant. While the spectrometer operates at about 20 mbar, the pressure against the dry side of the membrane was maintained at about $30 \mathrm{mbar}$. 
Gas permeation through a membrane depends on the solubility-in the membrane itself, followed by diffusion (migration of molecules through the membrane lattice) and finally evaporation out of the membrane. ${ }^{27}$ It is well known that the partial pressure difference of a given gas species controls the diffusion across the membrane and therefore the response time of the extraction system. Other parameters affecting the permeation efficiency are the membrane thickness, water flow over the membrane and ambient temperature: lower thickness, larger flow and higher temperature lead to higher permeability, and therefore faster response time. With respect to the membrane properties, a higher temperature increases the free volume as well as the mobility of the polymer chain, leading to higher diffusivity of gases through the membrane. With respect to any given gas, higher temperature means higher mobility, diffusivity and permeability. Water flow and temperature therefore need to be accurately and precisely controlled for an optimal behavior of the membrane extraction system. Biofouling, salinity, pressure and $\mathrm{pH}$ of the water may also affect the efficiency of the permeability, but, apart from salinity, this has not been investigated here, and it will require further investigation.

In our setup, two $10 \mu \mathrm{m}$ thick polydimethylsiloxane (PDMS) membranes of $56 \mathrm{~mm}$ diameter, were mounted face-to-face in a stainless steel housing in order to double the membrane surface. The membranes were simultaneously flushed with the water sample using a submersible water pump (Sea-Bird Electronics, SBE 5T) providing a flow of $0.8 \mathrm{~L}$ $\min ^{-1}$. The membranes were supported by porous bronze frits of $3 \mathrm{~mm}$ of thickness (Poral, grade 20), providing mechanical strength for the membrane under high pressure differences. The membrane block was designed to ensure that the water sample continuously flushed the entire surface of the membranes (a schematic of the membrane block is reported in SI-3). 
The dissolved methane sensor runs on 24 VDC power supply, with $50 \mathrm{~W}$ nominal consumption. During the present study it was powered through an electromechanical coaxial cable allowing for long-term deployment, but the system can also run on 24 VDC battery packs. Long-term deployment endurance will be further limited by the gas storage capacity inside the instrument, and by the carrier gas flow. The instrument was successfully deployed while measuring continuously for up to $12 \mathrm{~h}$. A CTD unit (Aanderaa, Seaguard TD262a) was attached to the probe, providing salinity-, water temperature-, depth-, and dissolved oxygen data.

\subsection{The Site of Study}

The Sub-Ocean probe was deployed as proof-of-concept onboard the CNRS-INSU research vessel Téthys II in the northwest part of the Mediterranean Sea on July 12 and 13,2014 . Because of adverse meteorological conditions, the deployment was limited to an area with only $620 \mathrm{~m}$ of depth available. The first tests of the instrument were conducted at $\sim 200 \mathrm{~m}$ from Toulon's harbor $\left(43^{\circ} 6.20 \mathrm{~N}-5^{\circ} 56.73 \mathrm{E}\right)$ for proving its stability and functioning. Vertical profiles were obtained in an area between Fréjus and the Gulf of the Napoule, at $\sim 8 \mathrm{~km}$ from the coast $\left(43^{\circ} 24.89 \mathrm{~N}-7^{\circ} 00.61 \mathrm{E}\right)$, not far from the Gulf of Lions. The Gulf of Lions was a target site for measurement of dissolved greenhouse gases ${ }^{34}$ and sediment core analysis ${ }^{35}$ because of its particular hydrological $^{2}$ character, mainly marked by the presence of large fresh water incoming from the Rhone River (with a flux on the order of $1600 \mathrm{~m}^{3} \mathrm{~s}^{-1}$ ).

\subsection{The Laboratory Apparatus}

The schematic of the laboratory experimental setup is represented in Figure 1. It was composed of a $14 \mathrm{~L}, 21 \mathrm{~cm}$ diameter, $40 \mathrm{~cm}$ high aluminum chamber, containing about 8 L of ultrapure water (Milli-Q Type 1, Millipore Corporation) where a variable amount of 
$\mathrm{NaCl}$ (Merck, purity >99.5\%) was added for reproducing particular salinity conditions. Salinity was measured with a digital refractometer (Bellingham and Stanley, 38-51 Aquatic). The temperature of the water in the chamber was stabilized between 2 and $25^{\circ} \mathrm{C}$ using a water cooling system (RM6, Lauda) and monitored by an immerged PT1000.The pressure above the water was maintained at atmospheric pressure $(\sim 101.3$ $\mathrm{kPa}$ ). The water was continuously bubbled with a gas mixture composed of zero air (ALPHAGAZ 2, Air Liquide) and synthetic air containing $\mathrm{CH}_{4}$ at concentrations between 0 and 90 ppmv (SAPHIR 90 ppmv of $\mathrm{CH}_{4}$ in air, Air Liquide) by means of a diffuser installed at the bottom of the chamber. The role of the diffuser was to reduce the bubbles size and to achieve dissolved gas saturation in a short time. The dilution system consisted of two mass-flow-controllers (MFC1 and MFC2, Bronkhorst) delivering up to $100 \mathrm{sccm}$ (standard cubic centimeters per minute) of gas. Water circulation was provided by the SBE 5T pump, ensuring a well mix of water in the chamber. The pump and the diffuser were positioned at maximum distance from each other to allow the best homogeneity of the water sample during the measurement and to avoid trapping air bubbles in the extraction system. The water circulated on the wet sides of the membranes included in the membrane block (MB, cf SI-3) and dissolved gases were extracted on the dry side and further transferred to the Sub-Ocean spectrometer. A dry carrier gas flow (zero air, ALPHAGAZ 2, Air Liquide) was supplied by a 0-10 sccm mass flow controller (MFCGG) to the dry side of the membrane extraction system, for continuously flushing the permeated gases from the membrane. This maintained $\mathrm{CH}_{4}$ partial gas pressures at the lowest possible level on the dry side of the membrane in order to optimize the extraction efficiency and response time. A flowmeter (IQF+, Bronkhorst) was used for monitoring the total gas flow (composed of the carrier gas plus the dry and wet components of the extracted mixture, $\mathrm{MFC}_{\mathrm{TF}}$ ). $\mathrm{CH}_{4}$ concentration in 
the headspace of the calibration chamber was continuously monitored by a laser spectrometer based on the same principle as the Sub-Ocean instrument, but designed for laboratory purposes (headspace spectrometer in Figure 1). Ten sccm of the headspace gas was supplied to the headspace spectrometer, while the overflow was sent to an exhaust vent. For inter-comparison with the discrete sample technique, water samples were collected in $115 \mathrm{ml}$ vials. During collection, $1 \mathrm{ml}$ of $1 \mathrm{M} \mathrm{NaOH}$ was added in order to inhibit bacterial activity. The vials were fully filled and closed with butyl rubber caps and aluminum crimps tops. Subsequently, $5 \mathrm{ml}$ of the samples were replaced with pure nitrogen (Air Liquide) at atmospheric pressure and $20^{\circ} \mathrm{C}$. The samples were analyzed at the University of Troms $\emptyset$ by gas-chromatography under blind conditions. A ThermoScientific Trace 1310 GC equipped with a FID and a ThermoScientific TG-Bond Msieve 5A column was used with hydrogen as carrier gas $(10 \mathrm{ml} / \mathrm{min})$. The oven was operated at a constant temperature of $150^{\circ} \mathrm{C}$ and the system was calibrated with three external methane standards at 1.8, 19, and 1800 ppmv. Instrument precision was estimated based on the standard deviation of replicates, and found to be $4 \%$ of measured methane concentration.

\subsection{The calibration in the laboratory}

The challenge in quantifying variations in membrane permeability makes measurements performed by gas-extraction membranes rather uncertain. ${ }^{12}$ Therefore, we paid special attention for calibrating and evaluating the performance of the instrument under laboratory controlled conditions.

Both spectrometers used in the calibration apparatus (for measuring the headspace air and the dissolved gases, Figure 1) were calibrated using certified standard gas (Restek, Scott/Air Liquide 99 ppmv \pm 5\%). Different concentrations were obtained with a dilution system composed by MFC1 and MFC2 used in the calibration setup (cf Figure 
1). A linear response over the whole range of concentrations was obtained with a good agreement between the two devices (slope $1.090 \pm 0.0027, \mathrm{R}^{2}=0.99995$ in 2015 and slope $0.9926 \pm 0.003, R^{2}=0.99989$ in 2018. See SI-1 and SI-2).

After each change in concentration, once equilibration of the system was achieved (2-3 $\mathrm{h}$ was required depending on the flow of the bubbling mixture), $\mathrm{CH}_{4}$ concentrations were averaged for about $10 \mathrm{~min}$. With both instruments connected directly to the headspace, the measured $\mathrm{CH}_{4}$ concentration for individual mixing ratios was in good agreement with the concentration expected from the gas mixture production (SubOcean spectrometer: slope $=1.07 \pm 0.01, \mathrm{R}^{2}=0.99926$; headspace spectrometer: slope $=$ $\left.0.981 \pm 0.007, R^{2}=0.9996\right)$.

In order to relate the concentration of dissolved gas with respect to its abundance in the headspace in equilibrium with the liquid phase, the gas solubility in water is required. However, if we assume a system with two independent headspace volumes in contact with the same liquid volume, they will reach the same headspace concentration, $\left[\mathrm{CH}_{4}\right]_{\mathrm{g}}$, providing that the pressure and the temperature in the headspaces are equal. Therefore, for this experiment, knowledge of the gas solubility is not required (Figure 2a). The ratio $\left[\mathrm{CH}_{4}\right]_{\mathrm{g}} /\left[\mathrm{CH}_{4}\right]_{1}\left(\left[\mathrm{CH}_{4}\right]_{\mathrm{l}}\right.$ being the quantity of $\mathrm{CH}_{4}$ dissolved in water and $\left[\mathrm{CH}_{4}\right]_{\mathrm{g}}$ in the headspace) will depend on the solubility of $\mathrm{CH}_{4}$ and other air components (mainly $\mathrm{N}_{2}, \mathrm{O}_{2}, \mathrm{CO}_{2}$ and $\mathrm{Ar}$ ) in water, which depends on temperature, pressure, and salinity. When a membrane is positioned between the water volume and the second air reservoir (containing the air analyzed by the Sub-Ocean spectrometer; Figure 2b), the concentration in the latter will be affected by the membrane gas permeability. Here, the concentration of $\mathrm{CH}_{4}$ in the gas side of the membrane will differ from that in the headspace $\left(\left[\mathrm{CH}_{4}\right]_{\mathrm{g}}^{\prime} \neq\left[\mathrm{CH}_{4}\right]_{\mathrm{g}}\right)$. The concentration in the dry gas downstream from the membrane can be calculated directly from the headspace concentration by using the 
membrane permeability coefficients for $\mathrm{CH}_{4}, \mathrm{~N}_{2}$ and $\mathrm{O}_{2}$ (reported by $\mathrm{Robb}^{26}$ ) and the concentration of the species in air, with the following equation

$$
\left[\mathrm{CH}_{4}\right]_{g}^{\prime}=\frac{\mathrm{Pr}_{\mathrm{CH}_{4}} \cdot\left[\mathrm{CH}_{4}\right]_{g}}{\mathrm{Pr}_{\mathrm{N}_{2}} \cdot\left[\mathrm{N}_{2}\right]_{g}+\mathrm{Pr}_{\mathrm{O}_{2}} \cdot\left[\mathrm{O}_{2}\right]_{g}}
$$

where $\operatorname{Pr}$ values are the permeability coefficients expressed as the product of the diffusion rate times solubility and reported by Robb for $25^{\circ} \mathrm{C}$ and atmospheric pressure. The quantity $\frac{\mathrm{Pr}_{\mathrm{CH}_{4}}}{\mathrm{Pr}_{\mathrm{N}_{2}} \cdot\left[\mathrm{N}_{2}\right]_{g}+\mathrm{Pr}_{\mathrm{O}_{2}} \cdot\left[\mathrm{O}_{2}\right]_{\mathrm{g}}}$ corresponds to the enrichment factor $\left(\mathrm{m}_{\text {eff }}\right)$ in eq 2 , which is measured using our calibration setup for different temperatures and salinities. $\left[\mathrm{CH}_{4}\right],\left[\mathrm{N}_{2}\right]_{\mathrm{g}}$ and $\left[\mathrm{O}_{2}\right]_{\mathrm{g}}$ are the mixing ratios of methane, molecular nitrogen and oxygen in air, respectively. The presence of argon and $\mathrm{CO}_{2}$ can be neglected here because of their low abundance with respect to nitrogen and oxygen. In Figure $3 \mathrm{~b}, \mathrm{CH}_{4}$ concentrations of the dry gas permeating through the membrane and measured by the Sub-Ocean instrument has been plotted versus the expected concentrations calculated from the headspace gas content and silicon membrane permeability coefficients using eq 1 . The observed and calculated concentrations are in good agreement, with a slope of $0.975 \pm$ 0.027. The relatively large errors $( \pm 12 \%)$ are due to the uncertainty related to the measurement of the small dry gas flow permeating through the membrane and the water concentration in the gas flow. These errors could be reduced if a larger number of measurements were used for retrieving the enrichment factor (meff) related to the selectivity of the membrane to permeation.

Measuring the concentration of water vapor $\left[\mathrm{H}_{2} \mathrm{O}\right]_{\mathrm{g}}$ is required in order to retrieve the dissolved $\mathrm{CH}_{4}$ concentration, $\left[\mathrm{CH}_{4}\right]_{\text {dissolved, }}$, since water vapor flow will cause dilution of the measured gas mixture (as the carrier gas flow). This measurement was performed by the same OFCEAS spectrometer embedded in the Sub-Ocean probe 
simultaneously to the $\mathrm{CH}_{4}$ measurement. $\left[\mathrm{CH}_{4}\right]^{\prime}$ dissolved is then calculated from the following equation

$$
\left[\mathrm{CH}_{4}\right]^{\prime} \text { dissolved }=\frac{\left[\mathrm{CH}_{4}\right]_{\text {meas }} \times f_{t}}{f_{t}-f_{C G}-\left(f_{t} \times\left[\mathrm{H}_{2} \mathrm{O}\right]_{g}\right)} \times \frac{1}{m_{e f f}}
$$

where $\left[\mathrm{CH}_{4}\right]_{\text {meas }}$ is the methane concentration in mixing ratio measured by the optical spectrometer, $f_{t}$ and $f_{C G}$ are the total- and carrier-gas flow $(\mathrm{ml} / \mathrm{min})$ respectively, and $\left[\mathrm{H}_{2} \mathrm{O}\right]_{\mathrm{g}}$ corresponds to the amount of water in mixing ratio permeating through the membrane. The complete denominator term $\left(f_{t}-f_{C G}-\left(f_{t} \times\left[\mathrm{H}_{2} \mathrm{O}\right] g\right)\right)$ corresponds to the dry flow permeating the membrane (Figure 3a). $m_{\text {eff }}$ represents the enrichment factor due to the membrane, and its dependency with temperature and salinity is calculated by running calibrations at different conditions, as reported for fresh water in SI-5. From this data, a $m_{\text {eff }}$ of $2.84 \pm 0.11$ for fresh water at $25^{\circ} \mathrm{C}$ and $120 \mathrm{KPa}$ was calculated. This is in agreement with an expected literature value of 2.76 calculated from the permeation coefficients reported by Robb 26 .

In this work, methane concentrations are reported as molar fraction (number of moles of the species over the total number of moles in the gas mixture, e.g. $\mu \mathrm{mol} \mathrm{mol}^{-1}$ or ppm) and as concentration per volume of water (nmol L-1) by employing Wiesenburg equations. ${ }^{36}$ Further information about unit conversion can be found in the SI.

\section{Results and Discussion}

\subsection{The Fast Response Time}

In order to establish the response time of the Sub-Ocean probe, the instrument was placed in a container with water open to the atmosphere, with the membrane block immersed into about $20 \mathrm{~L}$ of ultrapure water. At the beginning of the experiment, the instrument measured a concentration of $4.454 \pm 0.025 \mathrm{ppmv}$ of $\mathrm{CH}_{4}$. At time 00:00, 500 
$\mathrm{ml}$ of water enriched with a high concentration of dissolved $\mathrm{CH}_{4}$ was added to the water tank and a rapid $\mathrm{CH}_{4}$ increase was observed when the enriched methane solution was added (Figure 4). The curve resulting from the continuous measurements shows a double-exponential trend, which accounts for two contributions: a 46 s time constant exponential growth caused by the slow water mixing (dotted line), and a faster exponential growth profile (dashed line) with a time constant of $\sim 13 \mathrm{~s}\left(\tau_{90}=30 \mathrm{~s}\right)$ corresponding to the response time of the instrument. The time lag between the two exponential growth functions $(\sim 18 \mathrm{~s})$ is due to the fact that, while the water mixing takes place as soon as the enriched water is added, the instrumental response is delayed due to the transit time of the gas from the dry side of the membrane to the optical cavity inlet. The laboratory experiment described here simulates the detection of a natural source of $\mathrm{CH}_{4}$ leaking from the seabed, which was detectable in its full amplitude (up to 500 ppmv of $\mathrm{CH}_{4}$ ) by our instrument. The slow decreasing trend observed after the maximum is due to the progressive degassing of the dissolved methane from the water sample into the atmosphere. A mathematical approach based on the mass balance of such an analytical system has recently been developed by Gonzalez-Valecia et al. ${ }^{31}$. The model allows to retrieve the gas composition at any time, automatically correcting for the instrumental response time. This could also be applied to the Sub-Ocean instrument. However, it requires an accurate characterization of the system beforehand. In addition, considering the time scale of the Sub-Ocean measurement series presented here, such a correction is not of prime importance with respect to the small residual response time of the instrument $\left(\mathrm{t}_{90}=30 \mathrm{~s}\right)$. 


\subsection{Comparison with Discrete Measurements}

In order to prove the reliability of the extraction technique, a blind inter-comparison with standard headspace equilibration technique followed by GC analysis was performed. Seven independent measurements were conducted at different experimental conditions of temperature and salinity. The results are summarized in Table 1.

The concentrations measured by the Sub-Ocean spectrometer and by the GC from the discrete samples was compared to the continuous measure obtained by the spectrometer connected to the headspace. Slopes of $0.9830 \pm 0.044$ and $1.0016 \pm 0.019$ were obtained for SO/HS and DS/HS respectively (Figure 5). In the inset of Figure 5, the results from SO and DS were directly compared and resulted in a slope of $0.9831 \pm$ 0.031. The larger disagreement between the data corresponds to $18 \%$ for sample No.3 (at $10 \mathrm{ppmv}$ ) and $7.3 \mathrm{ppmv}$ for sample No.6 (60 ppmv) as reported in Table 1.

Four samples (1, 3, 4 and 5) were collected at different temperatures but similar concentrations (10 ppmv) and used for studying the reproducibility of the measurement with respect to the reference discrete sample method. Data are shown in Figure 6, highlighting a comparable accuracy between the SO and DS measurement. Average standard deviation for the four measurements at $10 \mathrm{ppmv}$ with respect to the HS measurement was $3.3 \%$ for the SO and $9.3 \%$ for the DS, while for the full set of the seven measurements it was $6.6 \%$ for SO and $7.6 \%$ for DS.

\subsection{Field measurements}

During the field campaign the probe was first tested by immersion at $10 \mathrm{~m}$ depth for $20 \mathrm{~min}$, allowing for verification of the stability of the instrument as well as the full functioning of the probe. This test was performed on July $12^{\text {th }}$ at the position $43^{\circ} 6.20 \mathrm{~N}$ $5^{\circ} 56.73 \mathrm{E}$, close to the Toulon seaport. An example of the resulting data is shown in Figure 7. The probe was immersed in water at 18:23 local time and reached $10 \mathrm{~m}$ depth 
after $50 \mathrm{~s}$. The probe was left at the same depth for about $20 \mathrm{~min}$, before being pulled up. The standard deviation of the $\mathrm{CH}_{4}$ measurements over 20 min of immersion was 0.16 ppmv. It should be noted that the instrument was calibrated for subsea measurements, therefore, the concentrations obtained in air (filled pattern area) are not correct, and are reported here as a time reference. Afterward, the vessel was moved to an area off the coast of Fréjus (position: $43^{\circ} 24.89 \mathrm{~N}-7^{\circ} 00.61 \mathrm{E}$ ), where we performed vertical profiles to greater depths. An example of the vertical profiles obtained is reported in Figure 8. Here, $620 \mathrm{~m}$ of depth were reached in only $10 \mathrm{~min}$.

A temperature-salinity plot of this profile can be found in the SI-6. The potential density anomaly increased from 26 to $28 \mathrm{~kg} \mathrm{~m}^{-3}$ from the surface down to $56 \mathrm{~m}$ (Figure 8e), highlighting a strong stratification dominated by the temperature (Figure 8c). Presence of fresh water above $56 \mathrm{~m}$ was observed through low salinity, but was concealed in the top $25 \mathrm{~m}$, where evaporation could be inferred through increased salinity toward the surface. The dissolved oxygen peaked at $56 \mathrm{~m}$, where the density stratification weakened, and tapered off toward $350 \mathrm{~m}$, but remained high down to the end of the profile at $620 \mathrm{~m}$.

The fast continuous measurements produced by the Sub-Ocean instrument provide more details (600 data points) in the dissolved methane profile compared to standard Niskin bottle sampling, where resolution is normally up to only 24 data points per depth profile. Methane concentrations were $13 \mathrm{ppmv}$ (15.4 nmol per liter of water) at the surface, and they reached a maximum of $26.7 \mathrm{ppmv}\left(30.2 \mathrm{nmol} \mathrm{L}^{-1}\right)$ at $6 \mathrm{~m}$ water depth. Descending towards $620 \mathrm{~m}, \mathrm{CH}_{4}$ concentrations decreased, approaching a minimum of $0.6 \mathrm{ppmv}\left(0.81 \mathrm{nmol} \mathrm{L}^{-1}\right)$ close to the bottom. Unfortunately, during the campaign there were no facilities for collecting discrete samples for comparison. Nevertheless, since our data correspond to background open ocean water conditions, 
indirect validation of the measurements can be done by comparing literature data of background dissolved $\mathrm{CH}_{4}$ in seawater. ${ }^{37}$

The relatively high methane levels observed at the surface $(0-56 \mathrm{~m})$, supersaturated with respect to the atmosphere, are typical of most marine waters. ${ }^{38}$ This is the so-called "marine methane paradox" where methane (normally resulting from the biological activity of strict anaerobes) is produced locally, while the surrounding environment is rich in dissolved oxygen. This phenomena could be due to aerobic bacterial degradation of phosphonate esters in dissolved organic matter as revealed recently through incubation of seawater. ${ }^{7}$ No cytometry measurements or other biological and kinetic analyses were performed during our test campaign and therefore, this hypothesis cannot be confirmed.

Another explanation for the $\mathrm{CH}_{4}$ profile could be that surface waters are mixed with incoming freshwater. Water masses from the Rhone river plume, for instance, are known to bear relatively large concentrations of dissolved methane, up to $1300 \mathrm{nmol} \mathrm{L-}$ ${ }^{1.34}$ A similarly $\mathrm{CH}_{4}$ enriched water source, for instance from the Var river, would also bear a minimum salinety signature. Such a signal appeared in our data set above $56 \mathrm{~m}$, (e.g. $\mathrm{S}=36.9$ at $24 \mathrm{~m}$ ) but is located deeper than the methane maximum, which discards the hypothesis of a freshwater anomaly to explain the methane one.

\section{Comments and Recommendations}

As shown in this initial work, the Sub-Ocean instrument opens new perspectives for continuous monitoring of dissolved methane (and possibly other dissolved gases) in sea- or lake waters. Its major advantages, compared with other instruments and sampling methods include (1) short response times ( $\left.\tau_{90}=30 \mathrm{~s}\right)$, (2) continuous in situ measurements which avoid biases associated with discrete sampling and subsequent 
laboratory analyses, (3) measurements that are immune to the presence of water vapor or to interferences by other species present in the gas mixture, (4) high sensitivity of the measurements $\left( \pm 25 \mathrm{ppbv}\right.$ in air, translating into $\pm 0.03 \mathrm{nmol} \mathrm{L^{-1 }}$ at $20^{\circ} \mathrm{C}$ and $38 \mathrm{psu}$ of salinity in water) obtained with the highly sensitive OFCEAS optical spectrometer embedded in the probe, allowing to measure anomalies in background concentrations, (5) a large dynamical range, covering five orders of magnitude in $\mathrm{CH}_{4}$ concentrations. Drawbacks of this approach are that (1) the measurement accuracy depends on the stability of the extraction system (and particularly on the water flow through the membrane) (2) enrichment factor (meff) will depends on the main components of the dissolve gas and particular calibrations are required for environments where nitrogen and oxygen are no longer the most abundant gas species.

This type of instrument could be employed for several applications such as studying the stability of methane hydrates in the seafloor, monitoring biological activity in seawater and lakes, checking leaks of natural gas pipes in deep water and pipelines inspection. The telemetry feature, available by powering the sensor using a battery, could provide real-time data at the surface via an electromechanical cable. This would allow quantification of the evolution of dissolved gas in real-time from the ship, enabling the design of more optimal ship-based sampling tracks. Here, we report the measurement of dissolved methane, but this type of optical spectrometer also allows to probe other target molecules such as $\mathrm{CO}_{2}, \mathrm{~N}_{2} \mathrm{O}$, and small hydrocarbons ( $\mathrm{C} 2$ and $\mathrm{C} 3$ ), or accessing to isotopic signatures of dissolved species such as $\delta^{13} \mathrm{C}$ and $\delta \mathrm{D}$ of $\mathrm{CH}_{4}, \delta^{13} \mathrm{C}$ of $\mathrm{CO}_{2}$ or directly the isotopic signature of the water mass ( $\delta \mathrm{D}$ and $\delta^{18} 0$ ). Further effort will be made to miniaturize the device as well as to reduce the power consumption $(50 \mathrm{~W}$ at the moment with respect to $15-20 \mathrm{~W}$ for a commercial instrument) in order to allow deployment of such dissolved gas sensors on UUVs (Unmanned Underwater Vehicles). 


\section{References}

(1) Gentz, T.; Damm, E.; Schneider von Deimling, J.; Mau, S.; McGinnis, D. F.; Schlüter, M. A water column study of methane around gas flares located at the West Spitsbergen continental margin. Cont. Shelf Res. 2014, 72, 107-118.

(2) Ruppel, C. D.; Kessler, J. D. The interaction of climate change and methane hydrates. Rev. Geophys. 2017, 55, 126-168.

(3) Bollmann, M.; Bosch, T.; Colijn, F.; Ebinghaus, R.; Froese, R.; Güssow, K.; Khalilian, S.; Krastel, S.; Körtzinger, A.; Langenbuch, M.; et al. World Ocean Review, Living with the oceans - A report on the state of the world's oceans; 2010; Vol. WOR 1.

(4) Grossart, H.; Frindte, K.; Dziallas, C.; Eckert, W.; Tang, K. W. Microbial methane production in oxygenated water column of an oligotrophic lake. PNAS 2011, 6 (49), 19657-19661.

(5) Damm, E.; Helmke, E.; Thoms, S.; Schauer, U.; Nothig, E.; Bakker, K.; Kiene, R. P. Methane production in aerobic oligotrophic surface water in the central Arctic Ocean. Biogeosciences 2010, 7, 1099-1108.

(6) Karl, D. M.; Beversdorf, L.; Bjorkman, K. M.; Church, M. J.; Martinez, A.; Delong, E. F. Aerobic production of methane in the sea. Nat. Geosci. 2008, 1 (7), 473-478.

(7) Repeta, D. J.; Ferrón, S.; Sosa, O. A.; Johnson, C. G.; Repeta, L. D.; Acker, M.; DeLong, E. F.; Karl, D. M. Marine methane paradox explained by bacterial degradation of dissolved organic matter. Nat. Geosci. 2016, 9 (12), 884-887.

(8) Dohan, K.; Maximenko, N. Monitoring ocean currents with satellite sensors. Oceanography 2010, 23 (4), 94-103.

(9) Gentemann, C. L.; Meissner, T.; Wentz, F. J. Accuracy of Satellite Sea Surface Temperatures at 7 and 11 GHz. IEEE Trans. Geosci. Remote Sens. 2010, 48 (3), 10091018. 
(10) Abraham, J. P.; Baringer, M.; Bindoff, N. L.; Boyer, T.; Cheng, L. J.; Church, J. A.; Conroy, J. L.; Domingues, C. M.; Fasullo, J. T.; Gilson, J.; et al. A review of global ocean temperature observations: implications for ocean heat content estimates and climate change. Rev. Geophys. 2013, 51, 450-483.

(11) Schlüter, M.; Linke, P.; Suess, E. Geochemistry of a sealed deep-sea borehole on the Cascadia Margin. Mar. Geol. 1998, 148 (1-2), 9-20.

(12) Boulart, C.; Connelly, D. P.; Mowlem, M. C. Sensors and technologies for in situ dissolved methane measurements and their evaluation using Technology Readiness Levels. TrAC - Trends Anal. Chem. 2010, 29 (2), 186-195.

(13) Chua, E. J.; Savidge, W.; Short, R. T.; Cardenas-valencia, A. M.; Fulweiler, R. W. A Review of the Emerging Field of Underwater Mass Spectrometry. Front. Mar. Sci. 2016, 3 (209).

(14) Newman, K. R.; Cormier, M.; Weissel, J. K.; Driscoll, N. W.; Kastner, M.; Solomon, E. A.; Robertson, G.; Hill, J. C.; Singh, H.; Camilli, R.; et al. Active methane venting observed at giant pockmarks along the U. S . mid-Atlantic shelf break. Earth Planet. Sci. Lett. 2008, 267, 341-352.

(15) Wankel, S. D.; Huang, Y.-W.; Gupta, M.; Provencal, R.; Leen, J. B.; Fahrland, A.; Vidoudez, C.; Girguis, P. R. Characterizing the distribution of methane sources and cycling in the deep sea via in situ stable isotope analysis. Environ. Sci. Technol. 2013, $47(3), 1478-1486$.

(16) Michel, A. P. M.; Wankel, S. D.; Kapit, J.; Sandwith, Z.; Girguis, P. R. In situ carbon isotopic exploration of an active submarine volcano. Deep. Res. Part II 2017.

(17) Faïn, X.; Chappellaz, J.; Rhodes, R. H.; Stowasser, C.; Blunier, T.; McConnell, J. R.; Brook, E. J.; Preunkert, S.; Legrand, M.; Debois, T.; et al. High resolution measurements of carbon monoxide along a late Holocene Greenland ice core: 
evidence for in situ production. Clim. Past 2014, 10 (3), 987-1000.

(18) Grilli, R.; Marrocco, N.; Desbois, T.; Guillerm, C.; Triest, J.; Kerstel, E.; Romanini, D. Invited Article : SUBGLACIOR : An optical analyzer embedded in an Antarctic ice probe for exploring the past climate. Rev. Sci. Instrum. 2014, 85 (111301), 1-8.

(19) Morville, J.; Kassi, S.; Chenevier, M.; Romanini, D. Fast, low-noise, mode-by-mode, cavity-enhanced absorption spectroscopy by diode-laser self-locking. Appl. Phys. B 2005, 80 (8), 1027-1038.

(20) Morville, J.; Romanini, D.; Chenevier, M. W003031949, (Université J. Fourier, Grenoble FRANCE, 2003). WO03031949, 2003.

(21) Morville, J.; Romanini, D.; Kerstel, E. Cavity Enhanced Absorption Spectroscopy with Optical Feedback. In Cavity-Enhanced Spectroscopy and Sensing; Gagliardi, G., Loock, H.-P., Eds.; Springer Berlin Heidelberg, 2014; pp 163-209.

(22) Triest, J.; Chappellaz, J.; Grilli, R. Patent 08276-01: System for fast and in-situ sampling of dissolved gases in the ocean (CNRS, Grenoble FRANCE, 2017). 8276-1.

(23) Chappellaz, J.; Alemany, 0.; Romanini, D.; Kerstel, E. The IPICS « oldest ice» challenge : a new technology to qualify potential sites. Ice Snow 2012, 4, 57-64.

(24) Fischer, H.; Severinghaus, J.; Brook, E.; Wolff, E.; Albert, M.; Alemany, O.; Arthern, R.; Bentley, C.; Blankenship, D.; Chappellaz, J.; et al. Where to find 1.5 million yr old ice for the IPICS “Oldest-Ice” ice core. Clim. Past 2013, 9 (6), 2489-2505.

(25) Lin, D.; Ding, Z.; Liu, L.; Ma, R. Gas Permeation through Polydimethylsiloxane Membranes: Comparison of Three Model Combinations. Chem. Eng. Technol. 2012, 35 (10), 1833-1841.

(26) Robb, W. L. Thin silicon membranes. Their permeation properties and some applications. Ann. N. Y. Acad. Sci. 1968, 146, 119-137.

(27) Zhang, H.; Cloud, A. The permeability characteristics of silicone rubber. SAMPE Fall 
Tech. Conf. Glob. Adv. Mater. Process Eng. 2006, 72-75.

(28) Merkel, T. C.; Bondar, V. I.; Nagai, K.; Freeman, B. D.; Pinnau, I. Gas sorption, diffusion, and permeation in poly(dimethylsiloxane). J. Polym. Sci. Part B Polym. Phys. 2000, 38 (3), 415-434.

(29) Mavroudi, M.; Kaldis, S. P.; Sakellaropoulos, G. P. A study of mass transfer resistance in membrane gas-liquid contacting processes. J. Memb. Sci. 2006, 272 (1-2), 103115.

(30) Atchariyawut, S.; Feng, C.; Wang, R.; Jiraratananon, R.; Liang, D. T. Effect of membrane structure on mass-transfer in the membrane gas-liquid contacting process using microporous PVDF hollow fibers. J. Memb. Sci. 2006, 285 (1-2), 272281.

(31) Gonzalez-valencia, R.; Magana-rodriguez, F.; Gerardo-nieto, O.; Sepulveda-jauregui, A.; Martinez-cruz, K.; Walter-anthony, K.; Baer, D.; Thalasso, F. In Situ Measurement of Dissolved Methane and Carbon Dioxide in Freshwater Ecosystems by Off-Axis Integrated Cavity Output Spectroscopy. Environ. Sci. Technol. 2014, 48, 1142111428.

(32) Schlüter, M.; Gentz, T. Application of Membrane Inlet Mass Spectrometry for Online and In Situ Analysis of Methane in Aquatic Environments. J. Am. Soc. Mass Spectrom. 2008, 19 (10), 1395-1402.

(33) Schmidt, M.; Linke, P.; Esser, D. Recent Development in IR Sensor Technology for Monitoring Subsea Methane Discharge. Mar. Technol. Soc. J. 2013, 47 (3), 27-36.

(34) Marty, D.; Bonin, P.; Michotey, V.; Bianchi, M. Bacterial biogas production in coastal systems affected by freshwater inputs. Cont. Shelf Res. 2001, 21, 2105-2115.

(35) García-garcía, A.; Orange, D.; Lorenson, T.; Radakovitch, O.; Tesi, T.; Miserocchi, S.; Berné, S.; Friend, P. L.; Nittrouer, C.; Normand, A. Shallow gas off the Rhône prodelta, 
Gulf of Lions. Mar. Geol. 2006, 234, 215-231.

(36) Wiesenburg, D. A.; Guinasso, N. L. Equilibrium solubilities of methane, carbon monoxide, and hydrogen in water and sea water. J. Chem. Eng. Data 1979, 24 (4), $356-360$.

(37) Bates, T. S.; Kelly, K. C.; Johnson, J. E.; Gammon, R. H. A reevaluation of the open ocean source of methane to the atmosphere. J. Geophys. Res. 1996, 101 (D3), 69536961.

(38) Reeburgh, W. S. Oceanic Methane Biogeochemistry. Chem. Rev. 2007, 107, 486-513.

(39) Fofonoff, N. P.; Millard Jr., R. C. Algorithms for computation of fundamental properties of seawater. Unesco Tech. Pap. Mar. Sci. 1983, 44, 53.

\section{Acknowledgements}

The research leading to these results has received funding from the European Community's Seventh Framework Programmes ERC-2011-AdG under grant agreement $\mathrm{n}^{\circ} 291062$ (ERC ICE\&LASERS), as well as ERC-2015-PoC under grant agreement no. 713619 (ERC OCEAN-IDs). This study is also a part of CAGE (Centre for Arctic Gas Hydrate, Environment and Climate), Norwegian Research Council grant no. 223259). The Téthys II ship time for the probe deployment in the Mediterranean Sea was provided by the Commission Nationale de la Flotte Côtière of CNRS-INSU. We deeply thank the captain of Téthys II Dany Deneuve and his crew, as well as the personnel of DT-INSU and IFREMER at La Seyne sur Mer, for their help in setting up and deploying the probe.

We acknowledge the SATT Linksium of Grenoble, France, and the Service Partenariat \& Valorisation (SPV) of the CNRS for their support to fund the SUBOCEAN project and to 
evaluate the valorisation potential of the Sub-Ocean instrument. We thank Dominique Lefevre, Christian Tamburini at MIO-Marseille and Thierry Penduff at IGE-Grenoble for their useful comments. 


\section{Figures}

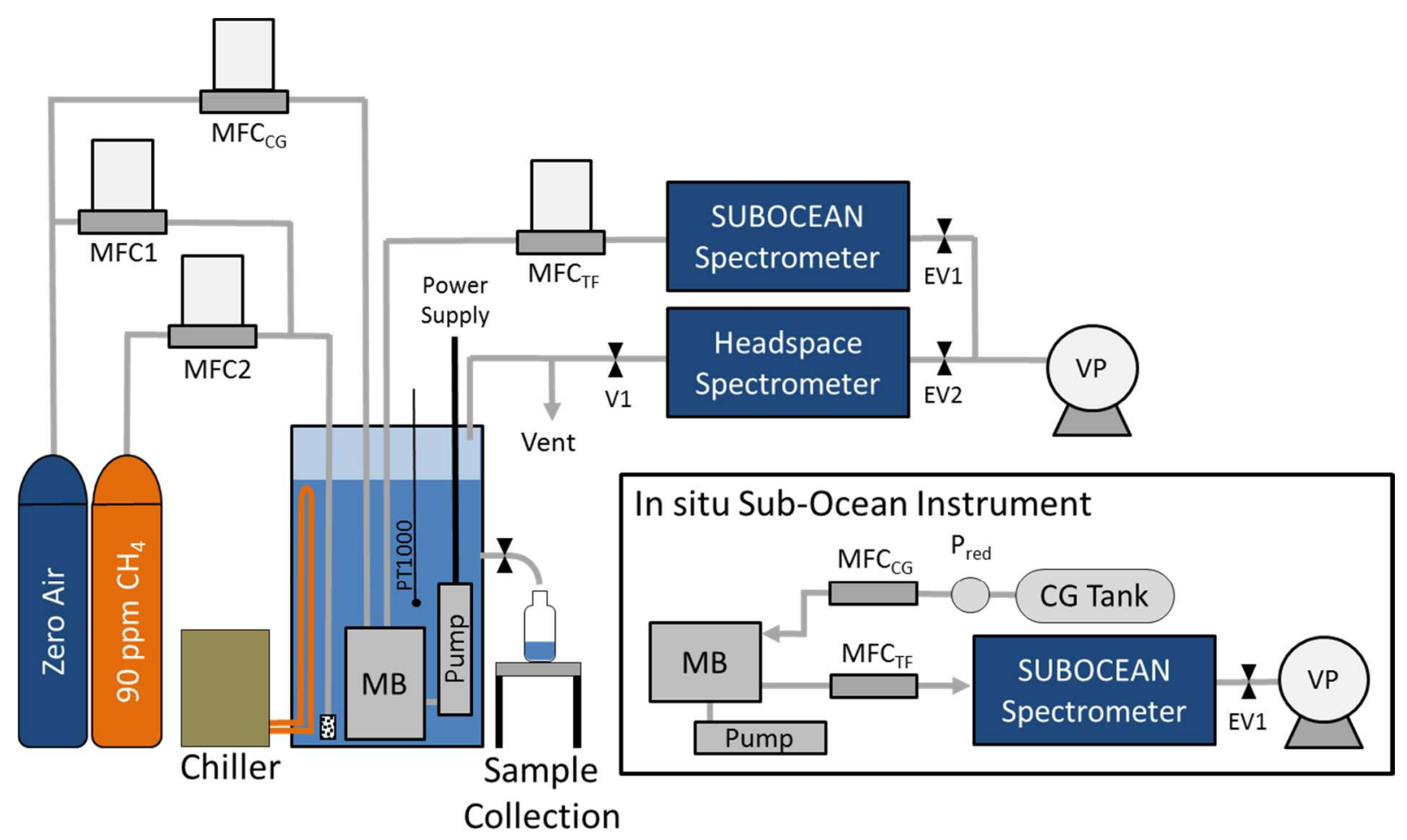

Figure 1. Experimental setup for laboratory tests. Two mass flow controllers (MFC1 and MFC2) have been employed to bubble different mixtures of $\mathrm{CH}_{4}$ in air into the water sample via a diffuser place in the liquid solution. The membrane block (MB) and the water pump are immersed into the water sample, stabilized in temperature using an external chiller unit. The dry side of the membrane is continuously flushed with a small (1 to $6 \mathrm{sccm}$ ) dry gas flow supplied by the $\mathrm{MFC}_{\mathrm{CG}}$, and the mixture (carrier gas plus extracted gas) is sent to the Sub-Ocean spectrometer. The total flow is measured by a fourth mass flow controller $\mathrm{MFC}_{\mathrm{TF}}$. A portion of the headspace $\mathrm{CH}_{4}$ concentration is monitored using a second optical spectrometer based on the same absorption spectroscopy technique (OFCEAS), while the overflow is sent to a vent. The exhausts of the analyzers are connected to two electronic valves (EV1 and EV2) and to a vacuum pump (VP) to ensure pressure regulation in the measurements gas cells. The inset shows the schematic of the in situ spectrometer, where the carrier gas flow is ensured using a gas tank and a pressure reducer, Pred. 


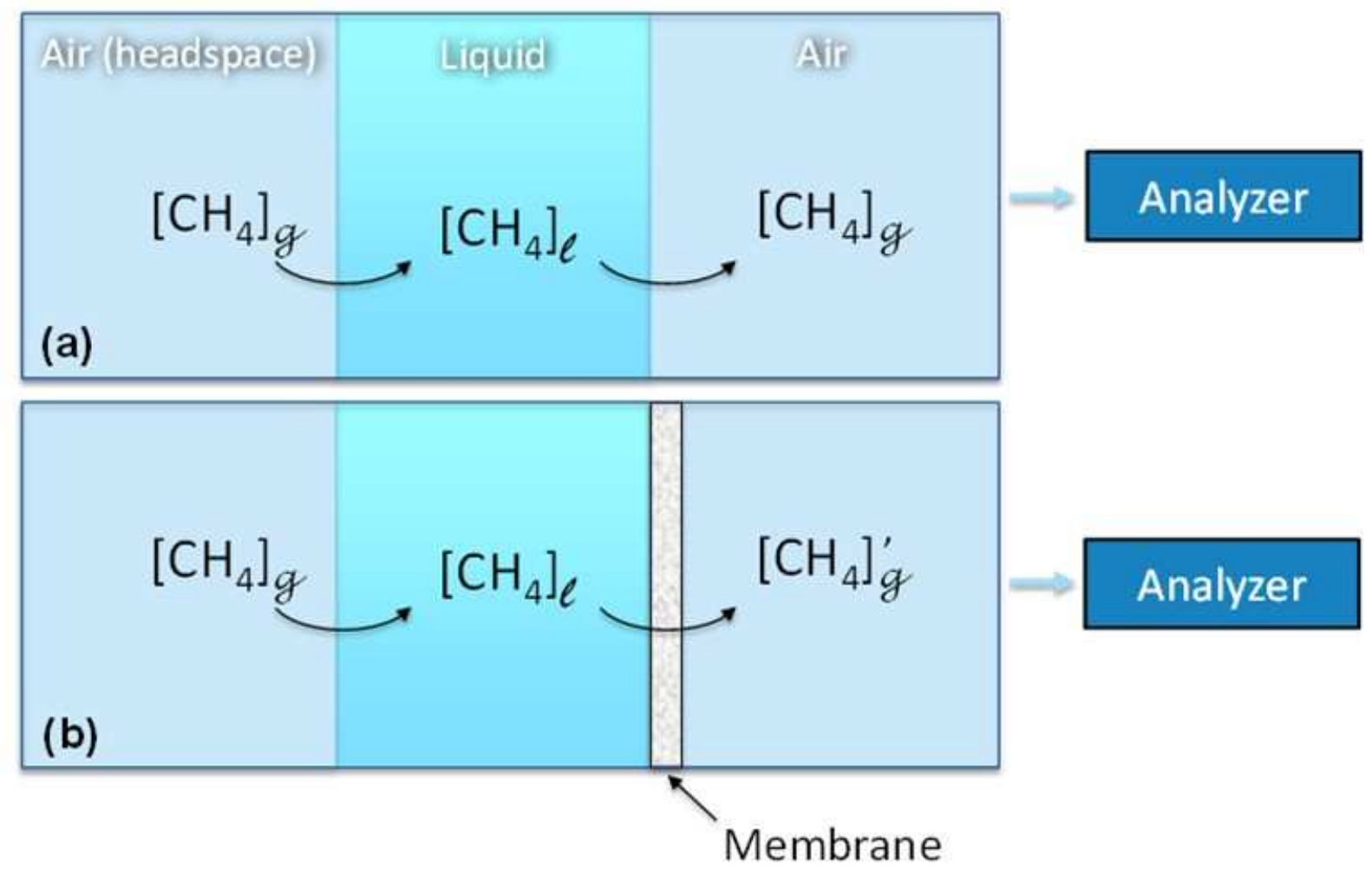

Figure 2. Schematic diagram showing the effect of a membrane for extracting dissolved gas. (a) represents the (ideal) case without a membrane; here, the concentration of $\mathrm{CH}_{4}$ at equilibrium found in the analyzed air will correspond to its concentration in the headspace. (b) In the presence of a membrane, the measured $\mathrm{CH}_{4}$ concentration will be affected by gas permeation through the membrane, resulting in a different measured concentration $\left[\mathrm{CH}_{4}\right]^{\prime} \mathrm{g}$. 


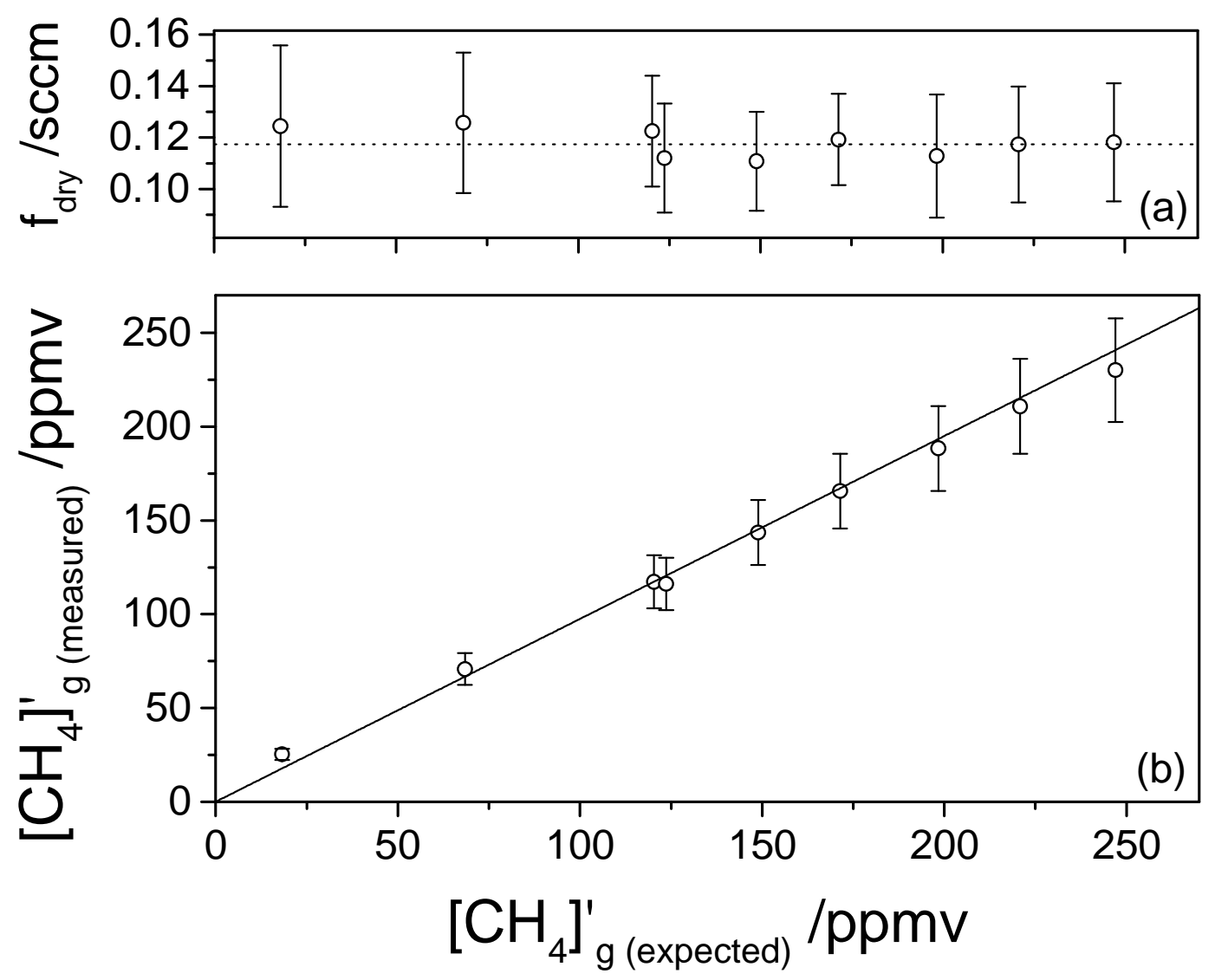

Figure 3. (a) Calculated flow of dry gas permeating through the membrane as a function of the expected methane concentration. The average flow is $0.1173 \pm 0.0017 \mathrm{sccm}$.(b) $\mathrm{CH}_{4}$ concentrations measured downstream from the membrane by the Sub-Ocean spectrometer are plotted against concentrations expected from the $\mathrm{CH}_{4}$ measured in the headspace, after accounting for the methane enrichment due to its preferential permeability through the silicon membrane, compared with molecular nitrogen and oxygen. The measurement was performed with unsalted water at $18^{\circ} \mathrm{C}$ and $120 \mathrm{kPa}$ of pressure. 


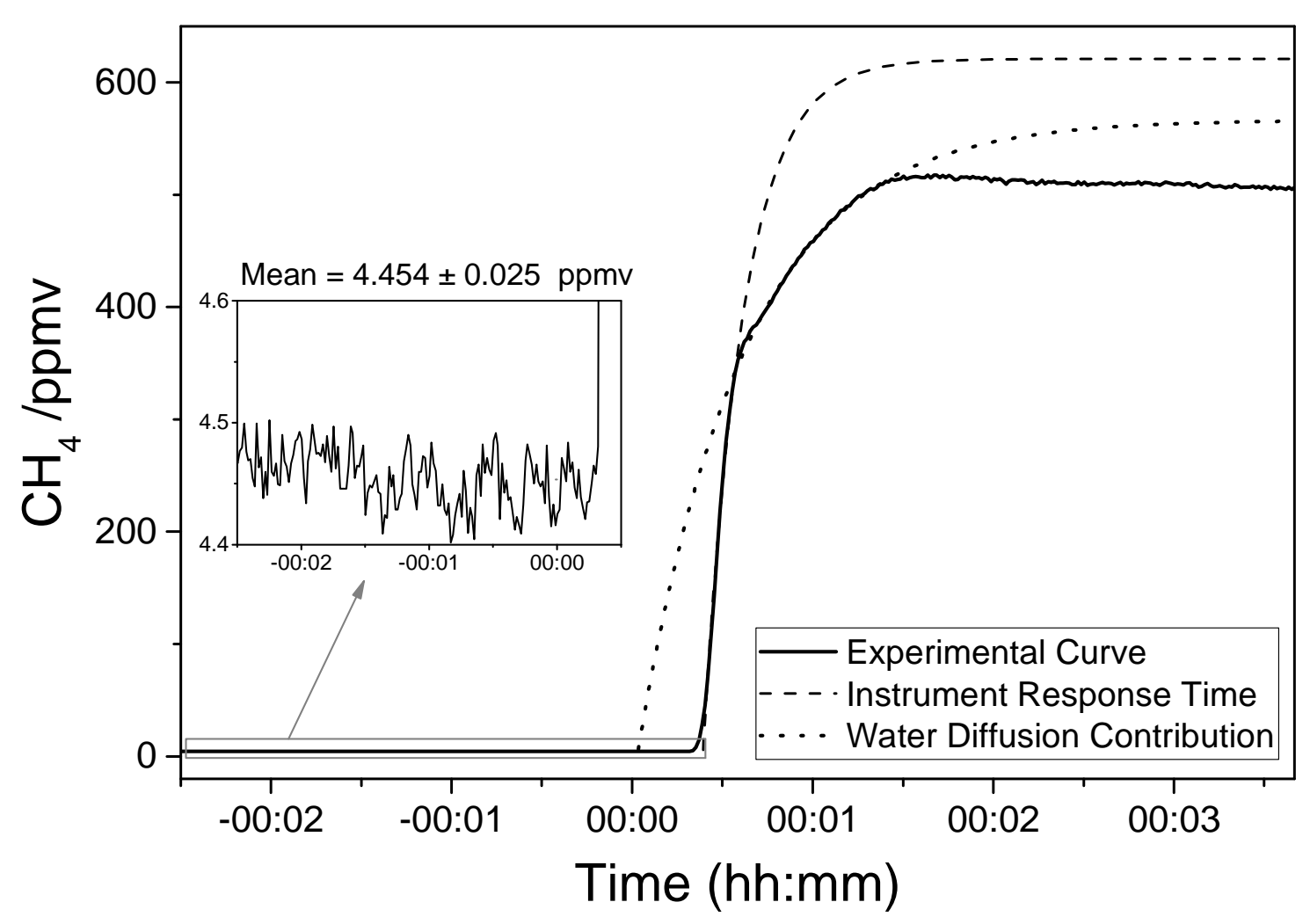

Figure 4. Typical response of the Sub-Ocean instrument when a water mass with high concentration of dissolved $\mathrm{CH}_{4}$ is added to the analyzed water sample. The curve can be fitted with a double-exponential growth function: a slow exponential (dotted line) accounting for water mixing contribution, and a short one (dashed line) which corresponds to the instrument response time. The $\tau 90$ of this second component corresponds to $30 \mathrm{~s}$. A precision of $\pm 25 \mathrm{ppbv}$ is obtained on the baseline (inset frame). 


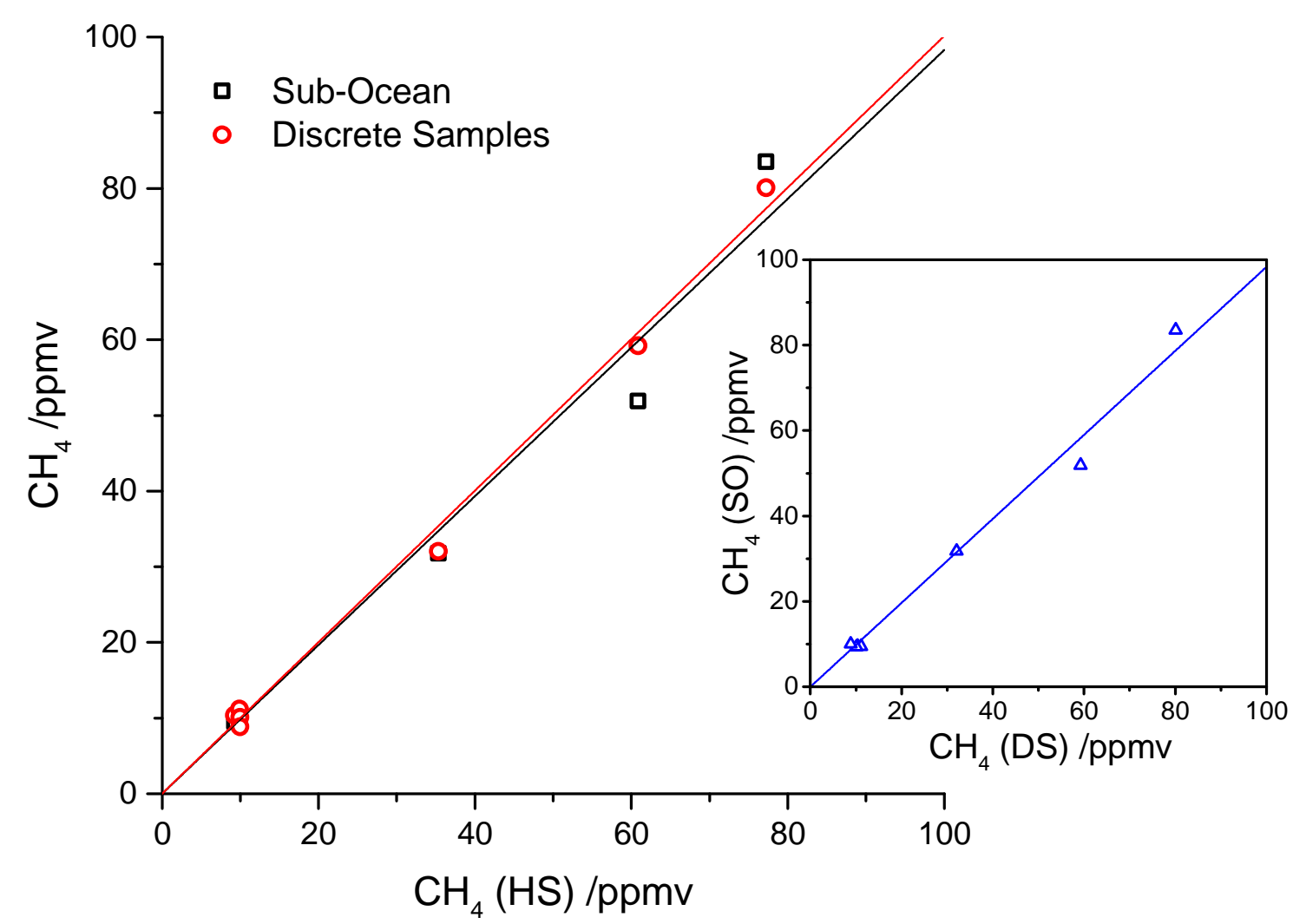

Figure 5. Results from a laboratory inter-comparison between the Sub-Ocean probe (SO) and the discrete sample method based on headspace equilibration followed by GC analysis (DS). In the main plot is shown the comparison of both techniques with the expected concentration measured by the headspace spectrometer (HS). In the inset plot is shown the direct comparison between the two experimental methods. 


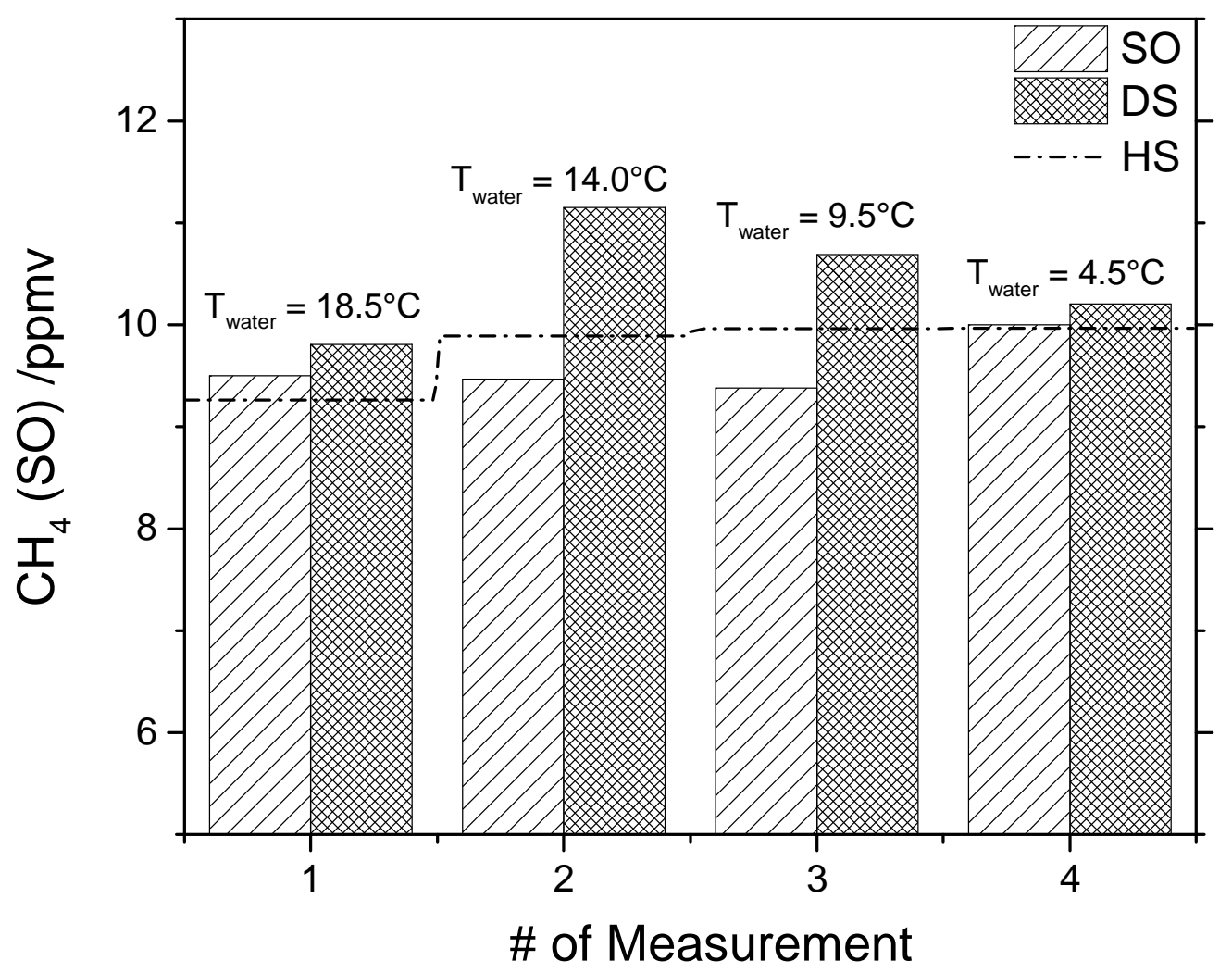

Figure 6. Reproducibility of Sub-Ocean (SO) and the discrete sample (DS) method at similar concentrations and different water temperatures. The dashed line shows the values expected from the headspace measurement during water equilibration and the bars show the measured values for both methods. Averaged standard deviation corresponds to 3.3 and $9.3 \%$ for SO and DS methods, respectively. 


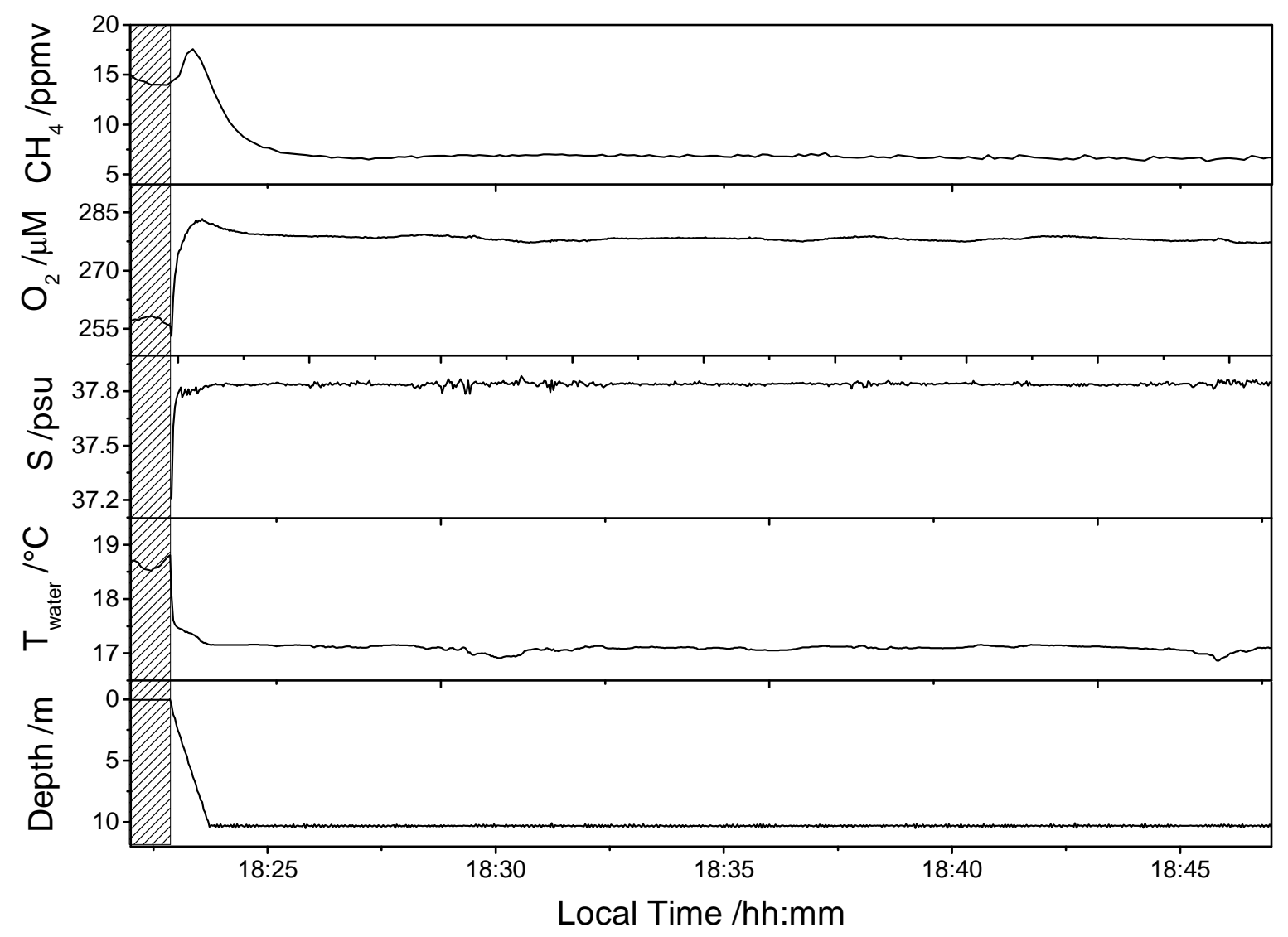

Figure 7. Static measurement at $10 \mathrm{~m}$ of depth for testing the Sub-Ocean system stability. This test was done on July $12^{\text {th }}, 2014$ at the position $43^{\circ} 6.20 \mathrm{~N}-5^{\circ} 56.73 \mathrm{E}$. In the plot is also reported the $\mathrm{O}_{2}$ concentration, temperature and salinity from a CTD that was attached to the instrument. The standard deviation on $\mathrm{CH}_{4}$ concentration at $10 \mathrm{~m}$ of depth over $20 \mathrm{~min}$ is $0.16 \mathrm{ppmv}$. 


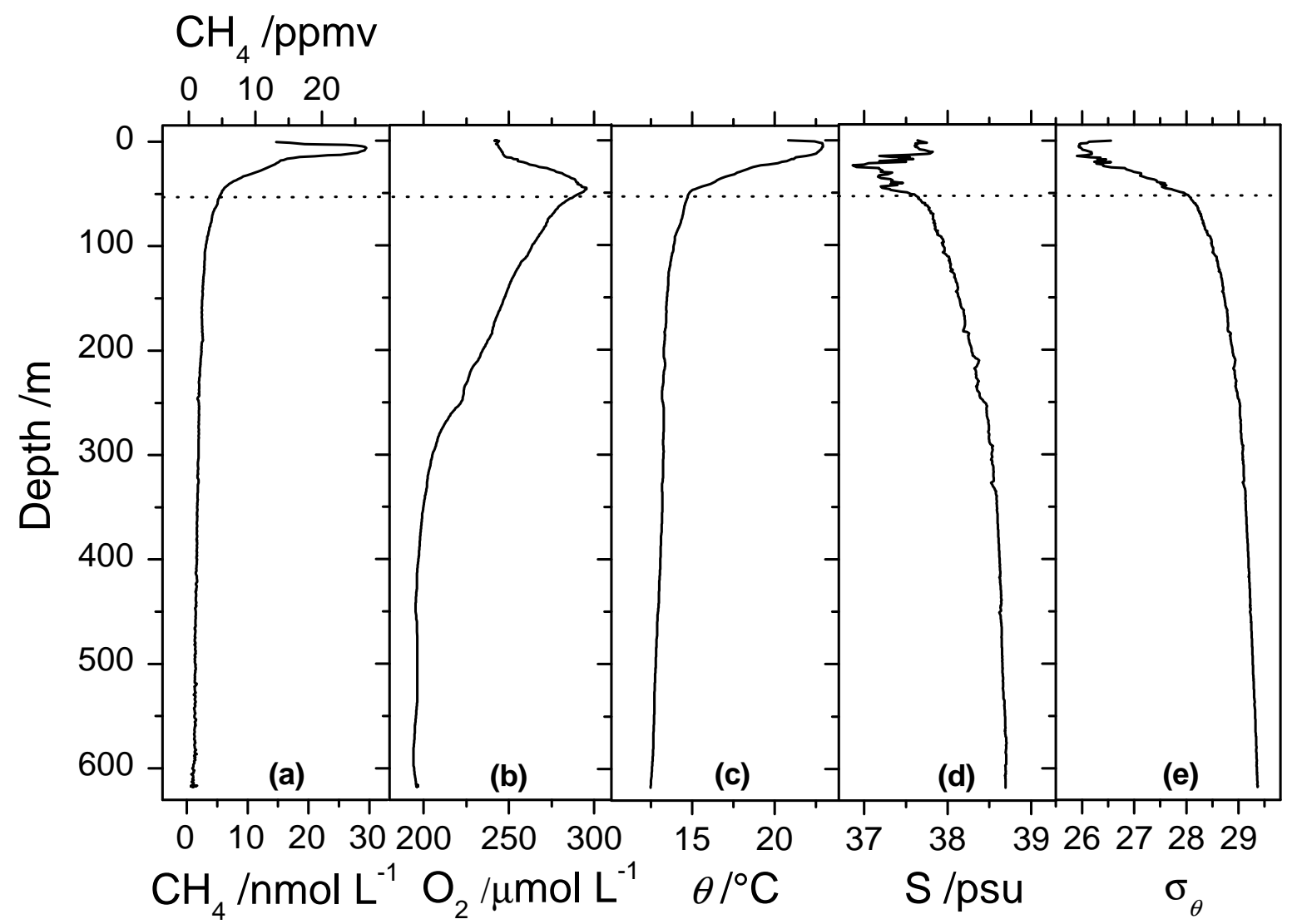

Figure 8. A continuous vertical profile of (a) $\mathrm{CH}_{4}$ (Sub-Ocean), (b) $\mathrm{O}_{2}$, (c) potential temperature, $\theta$, (d) salinity, $S$ and (e) potential density, $\sigma \theta$, recorded on July $13^{\text {th }} 2014$ at $3 \mathrm{~h} 50$ local time at the position $43^{\circ} 24.89 \mathrm{~N}-7^{\circ} 00.61$ E. Dissolved methane concentrations have been converted in nmol per liter of water considering the solubility of methane in water given by Wiesenburg, at 1 bar and at given temperature and salinity according to CTD data. Potential density has been calculated according to ref 39 . 


\section{Tables}

Table 1. Summary of the inter-comparison results. HS = headspace, $\mathrm{SO}=$ Sub-Ocean, DS = discrete samples.

\begin{tabular}{|c|c|c|c|c|c|c|c|}
\hline $\begin{array}{c}\text { Sample } \\
\text { no. }\end{array}$ & $\begin{array}{c}\text { T water } \\
\quad /{ }^{\circ} \mathbf{C}\end{array}$ & $\underset{/ p s u}{S}$ & $\begin{array}{c}\mathrm{CH}_{4} \mathrm{HS} \\
/ \mathrm{ppm}\end{array}$ & $\underset{/ p p m v}{\mathrm{CH}_{4} \mathrm{SO}}$ & $\begin{array}{c}\mathrm{CH}_{4} \mathrm{DS} \\
/ \mathrm{ppm}\end{array}$ & $\begin{array}{c}\Delta \% \\
\text { SO vs DS }\end{array}$ & $\begin{array}{c}\Delta \text { ppmv } \\
\text { SO vs DS }\end{array}$ \\
\hline 1 & 18.5 & 0 & 9.26 & 9.50 & 10.35 & 8.95 & 0.85 \\
\hline 2 & 18.4 & 0 & 77.23 & 83.52 & 80.09 & 4.11 & 3.43 \\
\hline 3 & 14 & 0 & 9.89 & 9.47 & 11.18 & 18.11 & 1.72 \\
\hline 4 & 9.53 & 0 & 9.96 & 9.38 & 10.09 & 7.59 & 0.71 \\
\hline 5 & 4.5 & 0 & 9.97 & 10.00 & 8.86 & 11.44 & 1.14 \\
\hline 6 & 5 & 30.5 & 60.85 & 51.90 & 59.21 & 14.08 & 7.31 \\
\hline 7 & 15 & 30.5 & 35.32 & 31.78 & 32.04 & 0.84 & 0.27 \\
\hline
\end{tabular}

